Etnográfica

Revista do Centro em Rede de Investigação em

Antropologia

vol. $13(2) \mid 2009$

Vol. $13(2)$

\title{
Kilimanjaro's melting glaciers: on the colonial and postcolonial perception and appropriation of African nature
}

O degelo dos glaciares do Kilimanjaro: percepção e apropriação colonial e póscolonial da natureza africana

\section{Urte Undine Frömming}

\section{(2) OpenEdition}

\section{Journals}

Electronic version

URL: https://journals.openedition.org/etnografica/1158

DOI: 10.4000/etnografica. 1158

ISSN: 2182-2891

\section{Publisher}

Centro em Rede de Investigação em Antropologia

\section{Printed version}

Date of publication: 1 November 2009

Number of pages: $395-416$

ISSN: 0873-6561

\section{Electronic reference}

Urte Undine Frömming, "Kilimanjaro's melting glaciers: on the colonial and postcolonial perception and appropriation of African nature", Etnográfica [Online], vol. 13 (2) | 2009, Online since 16 May 2012, connection on 12 February 2022. URL: http://journals.openedition.org/etnografica/1158 ; DOl: https:// doi.org/10.4000/etnografica. 1158

\section{(c) (†) (8)}

Etnográfica is licensed under a Creative Commons Attribution-NonCommercial 4.0 International License. 


\section{Kilimanjaro's melting glaciers: on the colonial and postcolonial perception and appropriation of African nature ${ }^{1}$}

\section{Urte Undine Frömming}

Over the past decade, the melting glaciers of Kilimanjaro have come to symbolise the effects of global warming. At the same time, increased tourism in the region has an ambivalent quality as the industry capitalises on the celebration of the same nature (and its western appropriation) that is threatened by tourism's major influence on world climate. In European perceptions, Mount Kilimanjaro has, since its first discovery in the $18^{\text {th }}$ century, become an epitome of overwhelming beauty, representing - until today - wilderness and adventure to the more than 20,000 international tourists who climb the mountain each year. This paper traces how these perceptions are grounded in the foundations of aesthetic modernity that continue to shape the attraction of Mount Kilimanjaro. Further examinations focus on the consequences for the local population as well as the relationships between local inhabitants and international visitors attracted by the scale-making projects of an industry that continues the colonial conquest.

KEYWORDS: Kilimanjaro, scale, tourism, nature, aesthetics.

\section{INTRODUCTION}

For many days, even weeks, it remains shrouded by clouds. But then suddenly it breaks through, seeming to float in the sky, higher than any mountain imaginable. Furrowed snowdrifts fall like frozen clouds into the depths. On the rooftop terrace of Kindoroko Hotel, exhausted Kilimanjaro tourists laze on

l German-language excerpts of this paper have been previously published (cf. Frömming 2004). The author wishes to thank Bariki Lyimo from Marangu and James Mongateco from Moshi, Tanzania, for their support of her fieldwork in the Kilimanjaro region in 200 1, Patrick Neveling and Carsten Wergin for comments to this paper, and Michael Kowen for polishing the text. 
lounge chairs, while the damp tropical air resounds with the distant ceaseless clamour of mobile phones ringing, cars hooting, and market vendors calling. Amidst all this, the snow-covered peak of Kilimanjaro emerges above russet, corrugated iron roofs, dull olive-green palms, and neem trees. Rather than dignity, the scenery induces a feeling which Descartes (1984 [1649]: 95, art. 53) called "the first of all the passions", that is, wonder. Unsurprisingly, one of the three mountains in the Kilimanjaro range is called "Kibo", a colloquial expression used by the local Chagga people to describe astonishment.

My main focus in this paper is the European "modern" appropriation of the Kilimanjaro region and the turns this appropriation has taken. While the local population's pre-colonial perceptions will be of some concern, I am particularly concerned with "modernity" in its contested form. Thus, I use the term in accordance with Randeiria (1999) to mean a form of "entangled modernities" of "many modernities" (see also Comaroff and Comaroff 1993: xi). This conception differs from other categories of modernity, such as Appadurai's "alternative modernities" (1996) or Larkin's "parallel modernities" (1997) which see a multiplicity of projects at work that are to some degree independent from each other. Instead, the notion of entangledness traces the interplay of forms and characteristics of modernities and emphasises their heterogeneous shapes and occurrences within translocal and transnational flows as well as the similarities within these flows (see Dilger and Frömming 2004: 7). In line with this global entangledness, I understand modernity according to Habermas (1985) as an unfulfilled process that has in the past seen harsh breaks and setbacks rather than followed a linear progression to a "better developed" society. Modernity therefore is not necessarily to be understood as a contrast to pre-modernity. In the Kilimanjaro region for example, some of the elder and younger Chagga still practice rituals that could be understood as pre-modern but are at the same time fascinated by the transregional prospects that international large-scale tourism offers. ${ }^{2}$ I therefore see both the local and the European reflections and their material outcomes as projects of scale-making (Tsing 2000, see also Neveling and Wergin 2009, this volume). In line with the concept of entangled modernities, I understand these projects as entangled on unequal grounds and thus put more emphasis on the European ideologies of scale, as they are, first of all, more powerful politically and also form the basis upon which the Kilimanjaro tourism industry as well as the global tourism industry work. Along with the latter's dominance in the economic realm come the negative effects on global climate.

2 In line with this observation, aesthetic and emotional aspects of "modernity" are not exclusively European in terms of their characteristics. I would rather raise the question of the dimension in which the African perception of Kilimanjaro is - not only since the spread of Christianity, but at all times - as well a religious, aesthetic and emotional imagination of the mountain and its surrounding landscape. 
Scale in relation to mountains, and particularly to the largest free-standing mountain in the world, seems an obvious point of reference. But taking history and its expressions into account, I hope to show that scale can be something quite different from the mere relation of a mountain to other mountains around the globe. As my discussion will show, the conflicting historical layers inscribed in the mountain's surface and its global representation as a natural miracle entail a reshaping of its physical appearance and a nearly canonical body of cultural industry products whose production began with the first European visits to the region.

As the Occidental natural sciences and the cultural sciences began splitting apart during the $19^{\text {th }}$ century, and science in general was in a phase of rapid redevelopment, it became more and more difficult for cultural and social researchers to enter the realm of nature (Groh and Groh 1996). At the same time, sensual experience was undergoing a repression in the art world (Seel 1996: 17), and for a long time aroused little more than passing scholarly interest. It is only gradually that social anthropologists and sociologists have begun to rediscover the realm of nature and aesthetic experience as an important field of inquiry (e.g. Bender 1993; Cosgrove 1993; Descola and Pálsson 1996; Luig 2002; Vietta and Kemper 1998). This is especially relevant when examining the European appropriation of non-European wilderness (cf. Wozniakowski 1987; Schama 1995) and its consequences for local societies. The partially unequal relationship that persists today is grounded in a historical process of appropriation. This helps to establish a first criterium of the large-scale versus small-scale distinction in that projects of scale-making and the resulting scalar positioning of societies and interest groups are grounded in networks and power relations. Size in terms of population numbers does not necessarily matter in this distinction (cf. Neveling and Wergin 2009, this volume).

Upon close examination, the aesthetic experience of the natural world proves itself to be an important area for anthropological research. Those particular places in nature which are marked by their beauty and uniqueness, which more or less resist human attempts to be transformed into landscape (e.g. mountains, waterfalls, rivers and oceans) have special cultural, political, and economic significance (Earle 2001; Cosgrove 1993; Frömming 2008). In her paper on Zimbabwe's Victoria Falls, the social anthropologist Ute Luig notes that the processes of marketing and representing nature have only recently begun to be discussed in scholarly literature, and mostly in reference to the European context. The African context still needs analysis, and even more urgently, "because tourism in eastern and southern Africa is also likely to cause radical changes in the attitudes of local inhabitants towards nature" (Luig 2002: 256). I would like to take this comment as a starting point for a deeper look into several aspects of the representation of Kilimanjaro, especially in aesthetics and in marketing, with particular reference to related large-scale 
tourism projects and their impact on the small-scale society of the Chagga people in Tanzania. ${ }^{3}$

\section{THE SPECIAL AESTHETICS OF KILIMANJARO: A HISTORICAL PERSPECTIVE}

Various authors have written about a shift in European perceptions of nature since the end of the nineteenth century. With a decreasing number of people working the land and the industrialization of agriculture, nature, as a site of production, became the landscape for an emotionally-loaded space of consumption (cf. Neumann 1998: 20), a place which satisfied emotional needs as well as feelings of identity and homeland (Luig and von Oppen 1997: 10ff.). The perception of mountains as sinister and unattractive obstacles, a standard known since antiquity, began to shift at the beginning of the $18^{\text {th }}$ century with the discovery of the "sublime" (Nicolson 1959) as a new type of aesthetic experience within the broader image of alpine scenery. As such, the mountain can be seen as an allegorical symbol of the Enlightenment, but also of colonial mastery and freedom from this mastery, which symbolically cumulated during the independence celebrations with the lighting of a flame on the highest point of Kilimanjaro (see below).

With the development of global mass tourism, non-European countries - and especially the former colonial territories - became a favourite holiday destination for people from the "disenchanted", "modern" West seeking new cultural adventures and aesthetic experiences of nature (Böhme 1995; Boomers 2004). During the colonial period, flows of trade had been established. Now, flows of tourism were also developing, transporting cultural "goods" and aesthetic experiences. In Western Europe and the USA of the $20^{\text {th }}$ century, the aesthetics of nature were no longer focused upon the familiar European landscape (e.g. alpine scenery), but also completely foreign realms of nature, be it tropical jungles, volcanoes or African savannahs and waterfalls. However, this shift was rarely mentioned in the aesthetic discourse of the time, which was marked by eurocentrism (Frömming 2006: 146ff). At the centre of this modern interest in the natural world stood strange localities which were often "holy places" for the local inhabitants (Colson 1997). This enormous interest in subtropical wildernesses and non-Western cultures can partially be explained by modern processes of rationalization, bureaucratization and secularization in the West, as described by theorists such as Hegel (1927-30) and Max Weber (1920).

3 For ethnographic studies of the Chagga, see Schanz (1913), Gutmann (1932-38), Dundas (1968 [1924]), Moore and Purrit (1977), Moore (1986), Winter (1994). The Chagga are also known as Chaga, Wachagga, Jagga and Dschagga. Beside the Chagga, Maasai people also live in the Kilimanjaro region. The Chagga are not a homogeneous group. In this paper, I focus mainly on the perspectives of mountain guides, porters and the rural population. Different perspectives would be found if the research was focused on intellectuals or business people among the Chagga population. 
These processes resulted in a desire for nonmaterial goods and therewith represented a significant shift in the development of Western modernity. This development led away from purely material appropriative interests (whether in entire countries or "just" in exotic foods) towards an aesthetic and emotional interest in adventures and experiences set in remote regions. However, it was also accompanied by very similar economic interests. It is in light of this history that this paper will examine Kilimanjaro. This specific place is a particularly notable example: it is the epitome of overwhelming beauty. It also embodies wilderness, adventure, and remoteness, thereby making it a magnet for international tourism. And more recently its shrinking snowcap has become a symbol and emblem of climate change. Beyond the aesthetic and symbolic features of Kilimanjaro and the history of European fascination with it, the following will also examine the consequences of these different facets of large-scale colonial and postcolonial interests (see Brandstetter and Neubert 2002) for the local Chagga groups involved in the tourism industry or living in the tourist areas of the Kilimanjaro region. However, the scope of this article allows for only a general sketch of the situation. ${ }^{4}$

The snow-covered peaks of Kilimanjaro soar above the surrounding lowlands of Tanzania, just three degrees below the equator. Ever since the first recorded mention by Ptolemy (ca. 90 to 160 AD), Kilimanjaro has enchanted European and US-American scientists, adventurers and tourists. Along with the wildlife at its foot, it has become the very symbol of Africa. Consisting of the three volcanoes Kibo, Mawenzi and Shira, it is not only the highest peak in Africa, at 5895 meters, it is also the tallest free-standing mountain in the world.

The most striking characteristics of Kilimanjaro are its snowcapped summit, which persists despite its equatorial latitude, and its free-standing position in an otherwise relatively flat landscape. The literary scholar Alexander Honold spoke of the "aesthetic improbability" of Kilimanjaro:

Looking at the surrounding steppes, this giant rock is neither climatologically nor morphologically "deducible". The mountain's visual effects are almost mystifying to the eyes of the European observer, even today; this is primarily due to the ineffable influence of atmospheric phenomena. In particular, the upper regions are frequently veiled in a thick layer of clouds, out of which the snowcapped summit most commonly emerges. In the right weather, this snowy peak has the optical effect of an ethereal apparition, floating high above the ground, making it obvious why the local inhabitants have traditionally considered this the seat of holiness [Honold 2000: 527, my translation].

4 My data is drawn from participatory observations of Kilimanjaro at Marangu, Moshi and Arusha, as well as interviews with local mountain guides, porters, agency operators, and European tourists during an ethnographic fieldwork in Tanzania in 2001. 
Another aesthetic and physical aspect of Kilimanjaro, which is radically challenged by the melting of its glaciers, is its permanence, its indestructible mass. According to Whitehead (1987 [1929]: 386), this concept of "the permanence of things" - such as the solid ground, the mountains, the Egyptian pyramids, the human spirit, and God - is in competition with the Heraclitean concept of "the flow of all things".

But Kilimanjaro possesses yet another geographical peculiarity, which Rousseau (1964 [1761]) once noted for the Alps: altitude and verticality allow for a wide variety of settlement and vegetation types to gather closely together. Humans' normally horizontal worldview, based on wide landscapes and flat surfaces, is surprisingly interrupted by the aesthetic view of the mountain as a vertical panorama, bringing together diverse topographies which contrast in both space and time. In the space of four or five days it is possible to hike from high summer at the foot of Kilimanjaro, through autumn in the middle forests and spring in the lobelia zone, to deepest winter on the summit, thereby experiencing each season.

The author of one of the first "encyclopaedic" compendia on the region, Walter Geilinger, described the sudden change in vegetation when crossing into the forest belt as follows:

At an altitude of approximately 1800 meters there is a rather sudden change in landscape, which had been monotonous until then. The trees stood thicker and stretched their horizontal branches higher. With just the first steep steps on this mountain giant we had already entered a new world, immersed in the marvellous kingdom of the Kilimanjaro forest [Geilinger 1930: 92, my translation].

The fascination of experiencing these layers of vegetation has remained to this day; it is a permanent aesthetic and emotional experience that places the mountain on a scalar hierarchy of global dimension (cf. Neveling and Wergin 2009 , this volume). The permanence of this project lives on in the imagination of most mountain climbers for whom the "peak experience" of the view from the summit is probably the highest point of aesthetic wonder, even when sometimes marked by major disappointments such as clouds. But most climbers are as satisfied as the early $2 \mathrm{I}^{\text {st }}$ century mountain tourist Kurt Benzer who experienced a sensually overwhelming triumph: "Conquered the peak. The sun rises blood-red over Africa. It is overwhelming". ${ }^{5}$ One could now engage in exploring the sun rising "blood-red over Africa" and how this is linked to the representation of the continent in European media. But there is a further

5 Kurt Benzer, 9/3/2002, at <http://www.Mount-Kilimanjaro.de>, Gipfelbuch section, accessed 15/12/2003. 
point to capitalise on here: the white male European as the conqueror. He conquers African nature and the aesthetic sensation is his individual experience, a kind of property that marks another permanence of European engagement with nature: the secular experience. As with Ptolemy or Rousseau, this layer of experience can be grounded in the Enlightenment-based project of scalemaking in human-nature relations; Petrarch's "stupefying" mountaintop experience of Mount Ventoux in the $14^{\text {th }}$ century has widely been interpreted as a turning away from religion-based engagements with the world in favour of aesthetically-based ones (cf. Groh and Groh 1996: 38). ${ }^{6}$

\section{"DISCOVERY” AND POLITICAL SKIRMISHES AROUND KILIMANJARO}

Various stories of a mountain supposedly full of djins or evil spirits who could not be chased away even by gunfire and who caused the immediate death of those who came too near had lured the German missionary Johannes Rebmann, equipped with a Bible and an umbrella, into the land of the "Jagga". His search for "superstitious" Africans who were to receive his "good news" led him to "the high mountain of Jaggaland", which he reached on the $11^{\text {th }}$ of May 1848. He saw a mountain "covered by a brilliant white cloud [...]. My guide described this whiteness simply as cold (badiri) and to me it was clear that it could be nothing other than snow" (Rebmann 1858: 30ff., my translation).

News of Rebmann's geographic discovery reached Europe. It was published in the Church Missionary Intelligencer in May 1849, but disregarded as mere fantasy for the next twelve years. The Geographical Society of London held that snow could not possibly occur let alone persist in such latitudes and considered the report to be the hallucination of a malaria-stricken missionary (cf. APG and Tanapa 2000: 18). European scientists were not yet ready to integrate Kilimanjaro's specific nature into their scalar hierarchy of natural phenomena. It was only in 1861 that researchers began their efforts to measure Kilimanjaro. Expeditions to Tanzania between 1861 and 1865, led by the German Baron Carl Claus von der Decken, confirmed Rebmann's report. Von der Decken visited Rebmann in Mombasa and contacted the chief of the Maasailand in order to find support for the expedition. He was able to climb Kilimanjaro in the year 1862 up to an altitude of 4000 meters (Honold 2000). But it was not before 1889 - three years after the English Queen Victoria had presented the African mountain to her nephew, the subsequent German King Wilhelm II, that the Leipzig geographer Hans Ludwig Meyer succeeded in measuring Kilimanjaro. He was accompanied by the Tyrol alpinist Ludwig Purtscheller

6 "At first I stood there as if stunned, moved by an unfamiliar gust of air and by a more liberated view", (Primum omnium spiritu quodam aeris insolito et spectaculo liberiore permotus, stupenti similis steti), quoted in Groh and Groh (1996: 38). Petrarch's letters appear in Thompson (1971). 
and the mountain guides Johana Lauwo and Jonathan Mtu, as well as seventeen porters. After several agonizing failures and frozen toes, hostage-taking by the local inhabitants and finally freedom through ransom payments, they reached the 5892-meters highest peak of Kilimanjaro in 1889, which Meyer patriotically named "Kaiser Wilhelm Peak". The sentence he uttered went down in history - or at least into a guidebook promoting tourism in the region in the 1920s: "With the privilege of being the first one to reach the summit, I christen this previously unknown, unnamed peak of the Kibo, the highest point of African and German soil: Kaiser Wilhelm Peak" (Meyer 1928: 46, my translation). ${ }^{7}$

Shortly after, serious skirmishes revolved around the colonial appropriation of the attractive new status symbol. Kilimanjaro became a bone of contention in the arena of European imperialism, with the British and Germans arguing over ownership of the "King of African Mountains". However, as in many other instances, particularly as seen in the Heligoland-Zanzibar swap, a simple barter exchange solved the problem. When Germany relinquished its claims to the equally disputed trade port of Mombasa, Kilimanjaro was finally awarded to Germany.

It was during the years of German occupation that the national and international marketing of Kilimanjaro began. One central mediator between the customers on the emerging global market for tourism and the businesses settling around the mountain was the same Hans Meyer who had first climbed the mountain. He took up the development of a geography department at his father's publishing house. Under his leadership the company printed a number of magazines and books that became famous on the German market, among them the Globus magazine and Brehm's Illustriertes Tierleben (Brehms's Illustrated Animal Life). Meyer also founded the series "Allgemeine Länderkunde" and "Meyers Reisebücher" (Universal Geography and Meyer's Travel Books). In 1909, he published a comprehensive two-volume compendium entitled Das deutsche Kolonialreich (The German Colonial Empire). On his list are also three books about the ascent of Kilimanjaro (Meyer 1888, 1900, 1928) and many others with titles as fancy as My Journey to the Kilimandscharo Range (Weiß 1886), The Kilimanjaro Expedition (Johnston 1886), Through Masai Land (Thomson 1885), The Kilimandscharo (Volkens 1897), and The Wachaga of Kilimanjaro (Morison 1933).

Thus, the news of the mountain's beauty spread within Europe. World history moved on, however, and following Germany's defeat in World War I,

7 From 1890 to 1918, the current territories of Rwanda, Burundi, and Tanzania (minus Zanzibar and Pemba) constituted Germany's fourth colony, German East Africa (see below). It is interesting to note here that the German adventurer was apparently aware of the local name of the peak, "Kibo", but mistook it for the general name of the mountain range. 
the Kilimanjaro region was annexed by the British. Although the two territories had become independent from Great Britain as separate political entities, Zanzibar and Tanganyika (former "German East Africa") joined together on the $26^{\text {th }}$ of April 1964, to establish what is today known as the Republic of Tanzania. A ceremonial peak of the independence celebrations was the lighting of a flame on the highest point of Kibo, which is also the highest point in Africa. "Kaiser Wilhelm Peak", which symbolized German imperial power and dominance, was renamed "Uhuru Peak", "Freedom Peak". The flame on Kilimanjaro became a symbol for Tanzanian independence, for justice and for hope. This is also highlighted in Julius Nyerere's speech as it was given on October 22 $2^{\text {nd }}$ 1959: "We the people of Tanganyika would like to light a candle and put it on top of Mount Kilimanjaro which would shine beyond our borders giving hope where there was despair, love where there was hate, and dignity where there was only humiliation." 8 This re-naming ceremony of the mountain could be interpreted following Homi Bhabha (1994: 139ff.) as a performative act of re-interpretation of a transnational symbol.

But similarly to most postcolonial African states, and particularly those following socialist ideals, Tanzanian state authorities imposed a certain project of modernization and strict control over the nation's territories shortly after independence (Escobar 1991: 675-676; Li 1999). As in other African countries, the boundaries of postcolonial Tanzania matched former colonial boundaries. These had been drawn according to the ideas of the European colonial powers. In extreme cases, territories had been swapped, as international recognition of the Kilimanjaro region as "German soil" had been bartered for German Reich's recognition of Mombasa as British. Thus, diverse populations that had very often had very diverse relationships with the former colonial rulers had to sort out projects of nation-building with one another. Development and nation-building were often closely linked because successful nation-building depended to a large extent on feeding the population. In this climate, the government adopted a strategy of economic development based on tourism. Not all of the interest groups in Tanzania went along with this governmental strategy, however, arguing that such a policy often contradicted the project of independence by relying on an obviously dependency-based economic endeavour (cf. Shivji 1973: x, quoted in Crick 1989: 321).

In the $19^{\text {th }}$ century, a yearning to climb Africa's white mountain had begun to take hold in Europe. And this yearning continued undisrupted by Tanzanian independence - and continues to this day. The various aesthetic charms of Kilimanjaro fascinated not only Europeans, but also Africans themselves. On a national level, this fascination became evident when the mountain was chosen as one of the sites representing the process leading to independence. 
But besides this history, layers of social organization and political hierarchy are also of relevance. The postcolonial state's promotion of tourism does not, as I will show in the following section, go along well with the local population's claims for rights and spiritual ownership of the mountain.

\section{THE SPATIAL EXCLUSION OF THE CHAGGA FROM KILIMANJARO}

One and a half million people who consider themselves members of an ethnic group called Chagga live around Mount Kilimanjaro. In 1897 the Germans established the so called hut-tax ("Hüttensteuer"). Each African adult man had to pay this tax on pain of penalties. Furthermore, Africans were forced to work on cash-crop farms (coffee, sisal, caoutchouc, cotton, peanuts). This form of forced labour destroyed the indigenous economy in many parts of East Africa. Many Chagga chiefs became German allies and helped the Germans subdue the Chagga and defeat rivals in other Chagga chiefdoms. The resisting chiefs were deposed or hanged, whereas the chiefs who cooperated were rewarded with power and commodities (cf. Semali and Kincheloe 1999: 7). At the same time, Christianity spread and most Chagga became Christians. The Churches, Catholic and Lutheran, were allocated religious control over many parts of the Kilimanjaro range.

The Chagga I spoke to in 2001 could only offer guesses on the origin of the extinct volcano's name, Kilimanjaro. Unlike the German colonizers or the postcolonial Tanzanian government, they never conducted a ceremony to name the mountain. The Chagga today claim that they had not climbed the mountain before Tanzania won independence in 1964. According to what they portray as their pre-Christian beliefs, it was (and for some it still is) forbidden to do so, because of respect for the mountain spirits. Therefore, if ever there had been an ascent, it could not have been recorded for fear of punishment. Today, many Chagga have been on top of the mountain as guides and porters employed in the bustling tourism industry. Inferences about the local aesthetic perceptions of the mountain can be derived from indigenous mythology and associated practices. ${ }^{9}$

The following describes how, despite colonization and Christian missionary activity, a strong religious connotation of nature has survived in secrecy among the local people until the present. This shows that in order for modernity to become and to stay entangled, it is sometimes necessary for differing perceptions of the spiritual qualities of a place to remain non-negotiated, to be kept secret. According to an 80-year-old man from Marangu, a small village at the foot of Kilimanjaro, traditional sacrificial rituals for the mountain are rare but still performed today. These rituals are known as tambiko, and must now be 
performed in secret. In particular, the pastor and the deeply religious Christians of the village must not hear about them. According to another informant, the practice of these rituals could, if discovered, lead to expulsion from the Christian community, "because Christians don't like to mix spirit (mizimu) and Jesus Christ. If Church leaders know this, they don't like you any more in Christian groups." 10 Therefore, when I was invited to participate in a family tambiko, ${ }^{11}$ it was scheduled at the same time as a Sunday church service.

My informant explained: "We do it now, because everybody who would not like it is at church on Sunday morning." If the business or problem to be solved involves just one family, then the ritual sacrifice is conducted behind that family's house, but if a drastic event occurs that involves the entire Chagga people, such as, according to Paulo M. Mlaj, drought, epidemics, intractable group conflicts and war, the ceremony will be conducted on the peak known as fuтии la mkиu ("skull of the ancestors") or Kifunika Hill, ${ }^{12}$ with an altitude of approximately 2900 meters, northwest of the Mandara Hut. The Chagga have never conducted a ceremony on Kibo itself, not only because of the difficulties of the ascent, but also as a sign of respect for njaro, the spirit who dwells in Kilimanjaro.

Among the coastal dwellers of Tanzania, the word njaro describes a demon of coldness. For the Maasai, the word njoro means wellspring or water, alluding to the many torrents flowing from the mountain. According to pre-Christian belief, the Chagga ancestral spirits and nature spirits, such as njaro, live together on Kilimanjaro. Sacrificial rituals had the function of communicating with these spirits and asking for fertility, health, the end of disaster or peace. At the same time, those rituals had social and economic meanings. They could be interpreted as a staging of gender-, clan-, or age-structures and other hierarchies, as well as a staging of the economic status of each person in the group. After the animal sacrifice (usually a goat), its parts are divided with extreme care. Each body part has a particular significance, corresponding to a particular clan member who has the right to that meat. ${ }^{13}$ The ritual I participated in was held for a (Christian) man who had lost his child and his wife. The ritual was meant to bring him a new wife and children.

10 Personal interview on 12/08/2001, Marangu.

11 On August $12^{\text {th }} 2001$ I participated in a sacrificial ceremony addressing family problems, in Marangu. The ceremony was documented on video.

12 Labelled on a map by my interview partner Morgan Minja (Marangu) at 47.8' longitude and 93.7' latitude.

13 The upper ribs (womoo mkaa) are given to the mother of the wife; the chest (kidari kya auyo) is given to the father of the husband or the clan eldest; the neck (mario waka) is given to the women; the front feet (kurende ko monawamae) are given to distant relatives; the legs (wanakye) are given to boys; the testicles are given to all male participants of the tambiko (including my camera man); the head of the animal is then wrapped in its skin, tied together, and left on the peak for the mizimu ("nature spirits"). 
Most Chagga do not speak of Kilimanjaro, but rather of its two highest peaks, Mawenzi ("black mountain") and Kipoo or Kibo ("white mountain"). The name Kilimanjaro has now become widespread through most of Tanzania, particularly due to its touristic attractions. The various geographical regions of the mountain are named after early chiefdoms. These emic or native namings that refer to collectives and groups rather than to individuals stand in stark contrast to those on colonial and postcolonial Tanzanian maps. Although Kilimanjaro's highest peak may no longer be called Kaiser Wilhelm Peak, its glaciers and other peaks are still named after European mountain climbers and missionaries (such as Hans Meyer Peak and Purtscheller Peak on Mawenzi and Rebmann Glacier, Decken Glacier and Furtwangler Glacier on Kibo).

\section{POSTCOLONIAL DEVELOPMENT AND THE TOURISM INDUSTRY'S APPROPRIATION OF KILIMANJARO}

The Tanzanian government and international organizations promoted the development of the international tourism economy in the Kilimanjaro range through several measures. In 1972, the Tanzanian government founded the Kilimanjaro National Park, in which certain zones were forbidden to local people, but paths were legally opened for tourists (cf. Hamilton and Worboys 2003: 1). This provides a clear case in point for the analysis of the social anthropologist Raoul Bianchi. He distinguishes the influence of tourism from agrarian and industrial capitalist development. With this distinction he gives tourism experiences a special function in appropriating space and constructing and transforming landscape, cultures and economies (Bianchi 2003: 18).

The tourist experience of walking through the Kilimanjaro terrain has been nurtured up to the point where the local population has been required to step aside. The landscape and also its value as a ritual site is neglected for the benefit of tourism marketing. Furthermore, in 1989, the Kilimanjaro region was declared an UNESCO World Heritage Site, and in 1993, the Kilimanjaro National Park General Management Plan took effect, providing a comprehensive legal framework for the protection of the mountain. Tanzania National Park (Tanapa) forbids not only wood collection and other harvesting of grass and plants, but also all types of recreational sports that undermine the appreciation of nature, such as skiing, motorsports (cars and motorcycles), hang gliding, and hot-air ballooning. Only hiking and mountain climbing are permitted, under the guidance of a local agency at Kilimanjaro National Park.

However, these measures cannot change the fact that Kilimanjaro's snowcap has lost 82 percent of its volume since 1912. Although the meltings' hydrological influence has not yet been fully researched, one can assume that it will have wide-reaching regional effects, since Kilimanjaro supplies water to a large part of Tanzania and East Africa. Further reductions in the snowcap, as a consequence 
of climate change, could have devastating consequences. The city of Moshi, at the foot of the mountain, has already suffered water shortages. While these reductions in the snowcap cannot be linked to tourism development per se, the latter has nevertheless a clear impact on water supplies. The problem of water shortage is exacerbated by the many hotel complexes that have intensive water consumption. Water consumption providing for the needs of visitors clearly surpasses the local water consumption scale. In this regard, various sources lament the disempowerment of local people in managing Kilimanjaro's ecosystem, as their scalar structuration of water use and abuse could serve as a guideline for tourist development, since this once meant an efficient system for the management of water resources, for example in planning irrigation:

The Chaggas demonstrated a strong attachment to their environment and they made concessions in order to ensure the sustainability of their natural system. These findings go against the "tragedy of the commons" type of models. For example, concerning the management of irrigation furrows, the local rules are issued from an ancestral system, which is still efficient today. [...] The organization of the Chagga society is based on cooperation and participation principles in order to reach equilibrium between human needs and nature preservation. Mount Kilimanjaro, which has belonged to the Chaggas for centuries, is slipping little by little out of their hands [Hamilton and Worboys 2003: 1].

Furthermore, with the demarcation of a boundary around the national park, ritual sites such as the aforementioned Kifunika Hill, one of the most important sacrificial grounds for the local inhabitants, are now within the park borders. As such, they can no longer be reached by the Chagga unless they pay an entry fee. ${ }^{14}$ Bianchi points out the related conflict potential in the construction of such World Heritage Sites:

The construction of heritage has a socio-spatial as well as an ideological dimension. [...] The declaration and promotion of World Heritage Sites is a particular case in point, whereby local attachment to historical places, monuments and landscapes may come into conflict with the policy goals of national and international conservationist institutions as well as the consumerist activities of tourists [Bianchi 2003: 25-26].

More than 20,000 tourists climb Kilimanjaro each year. To celebrate the turn of the millennium, nearly 3,000 tourists reached the mountain peak, 
although entry and overnight fees had been doubled. ${ }^{15}$ Ever since coffee prices tumbled on world markets, Kilimanjaro tourism has become one of the most important sources of income for Tanzania. The cities of Moshi and Arusha are the main hubs for Kilimanjaro mountain climbers. They offer numerous hotels and lodges with names like "Kibo Lodge" and "Kilimanjaro Hotel", where visitors can prepare themselves for the climb as well as recuperate afterwards. Most mountain tourists plan their travel far in advance, booking a tour company long before leaving home. Many combine the mountain ascent with a safari in Serengeti National Park or in the Ngorongoro Conservation Area. ${ }^{16}$ Since it is well-known that even the inexperienced can in principle climb Kilimanjaro, tours are also booked spontaneously at numerous local agencies, which often advertise the mountain-climbing adventure with a stereotypical image of an acacia tree and a herd of elephants standing below the snowcapped Kibo.

There are four different routes to the summit, which are each named after a locality or former chiefdom: Machame Route, Mweka Route, Umbwe Route, and the most commonly used Marangu Route. Among the locals, this last route is also called the "Coca-Cola Route", underlining their shifting understanding of what was once a ritual path to the sacrificial grounds reserved for the elders of the Marangu chiefdom and is now a thruway for global tourism.

\section{THE CHAGGA'S ECONOMIC POSITION WITHIN AND PERCEPTION}

\section{OF THE TOURISM INDUSTRY}

A six-day trekking tour costs between 650 and 750 us dollars, and is generally organized in groups of between five and twelve tourists, so as to make the expeditions more worthwhile for the organizer. The trek leader is usually European, while the mountain guide is usually Tanzanian, accompanied by an African cook, his assistant and around fifteen porters. The porters carry all the luggage, tents, food, cooking pots and even folding stools, while each tourist carries only a personal daypack. As can be expected, the mountain tourists come away with diverse experiences. Joy and pride predominate among those who achieve Uhuru Peak, the summit of Kilimanjaro. A great sense of personal satisfaction comes from conquering nature, and especially from overcoming one's physical weaknesses.

I interviewed several Chagga on the question of why they thought tourists would undertake the stresses of climbing Kilimanjaro. They cited reasons of physical fitness, financial motivations, and an interest in geography and culture. The local porters and guides saw tourism on Kilimanjaro not only as

15 See < http://www.marcinkowski.org/bergsport/touren/kibo/kibo_info2.htm>, accessed 25/1 1/2003.

16 The Ngorongoro Conservation Area is a wildlife protection area with National Park status, home to about 23,000 Maasai. 
an intellectual exchange, but also as a possibility to get to know people from other countries and exchange ideas about leisure-time activities. One guide commented: "We learn some good things from them: physical fitness, changing minds." ${ }^{17}$ It is also seen as an economic benefit. However, some mountain guides made the justified criticism that a tourist may pay around 450 US dollars for a six-day park permit, which benefits the national park administration, but pays only around 200 US dollars for transportation, guides, porters and food. The financial resources either available or estimated provide for different valorisation of what is offered. Tourists are asked to pay disproportional sums for services. This disproportion is justified by the fact that the preservation of a National Park, a World Heritage Site, must be more costly than the work of a local guide. Furthermore, some Chagga and Maasai are especially hardhit by the prohibitions on collecting wood and harvesting grass. This clearly demonstrates the different notions of how to use nature and the varying scales by which different groups define the economic value of the mountain region. Some of those who live next to the park's borders sometimes violate these prohibitions because they consider them unjustified. Instead, Chagga have their own criticism with regard to environmental pollution and destruction. Many guides and porters also complain about the costs of treating altitude sickness. In addition, they are not particularly happy that each mountain guide is required to pass a regular test for HIV, or else would lose the mandatory operating licence, which could easily lead to financial ruin. ${ }^{18}$ From the tourism industry's perspective thus it is the local guides and porters who present a risk to their customers whereas from another perspective, it is the tourism industry that threatens the livelihood of the local population - or at least does not create opportunities to end poverty. Modernity here again emerges as an entangled project where secrecy in terms of resource extraction, the ritual practice of HIV tests and economic success are similarly connected as in the local rituals described earlier.

On many levels, the example of Kilimanjaro confirms the aforementioned fact that tourism causes a basic shift in how people view their natural environment. In this particular case, the aesthetics of nature and landscape are perceived as a financial resource, at least for the local people involved in the tourism industry. These perceptions are part of a larger implementation process linked to the re-evaluation of Kilimanjaro as a World Heritage Site. I met many young Tanzanians who expressed a desire to study wildlife or tourism, in order to work in the national parks or the tourism industry. In addition, the

17 Interview with Bariki Lyimo on August $12^{\text {th }} 2001$ in Marangu.

18 Interviews with guides Morgan M., Bariki L. and James M. (from July $27^{\text {th }}$ to August $14^{\text {th }} 2001$ ). Open questions were sent by email from October 2001 to October 2003. During this time, our discussions allowed the guides to develop further responses to my questions. 
Tanzanian Minister for Natural Resources and Tourism, Zakia Meghji, introduced a program in 2001 to promote domestic tourism, hoping to encourage the tourist impulse among Tanzanians, so that they become more interested in their own national tourist attractions:

When we talk about promoting domestic tourism we mean sensitising Tanzanians to visit tourist attraction areas or investing in the sector. We all know that Tanzania is endowed with unique tourist attractions that pull thousands of tourists from all over the world. However, most citizens of this country have not been able to sample or enjoy the same tourist attractions due to either lack of financial capabilities or lack of tourism knowledge [Meghji 2001: 7].

\section{CONCLUSION}

The German anthropologist Ute Luig gives an apt description of the connection between nature conservation and international tourism:

Global strategies in relation to nature conservation have been defined by Western concepts and practices since the beginning of the conservation movement in the nineteenth century. These include not only the dispossession and expulsion of local peoples, but also the governmental implementation of Western ideas of nature conservation. Nature is conceptualized as the other, standing in opposition to culture instead of being a part of it, thus fulfilling the need for primevalness, timelessness and eternalness. However, the realization of this experience requires the tools of increasingly resource-intensive civilization - cars, airplanes, hotels and infrastructure which destroy precisely that idyll which one seeks to protect [Luig 2002: 271, my translation].

In this paper on tourism in the Kilimanjaro region, I have outlined a range of historically-grounded processes closely related to Luig's observation. The history of Kilimanjaro is composed not only of a history of sensory perception of African nature in the scale-making project of European modernity. Above all, it is a history of power, and of colonial as well as postcolonial conquest. When Seel (1996: 213) described the "moment of shock", it was within the context of modern art aesthetics, but its immense power can also be seen in the aesthetic perception of wilderness. This expresses itself as a projection of the outside world and as a quest for objectivity in the subjective consciousness of visitors and guests who experience their own limitations and finiteness when confronted with this outer wildness, infiniteness and freedom. This is the overwhelming moment of sensory contemplation described by Baumgarten 
(1750-58), Adorno (1973), Seel (1996) and other philosophers in the field of modern European aesthetics. The European appropriations of Kilimanjaro, with its economic and political implications, are a clear example of how aesthetic perception, which has been relegated for decades to the "harmless" world of art, precipitates cataclysmic social change embodied in a tourism industry and an ideology of scale. The modern Western traveller tries to experience every sensual thrill and physical extreme, in search for Utopian wilderness and African paradise:

With the last drop of champagne, and the sun setting upon a herd of wildebeest flowing past the panorama of Kilimanjaro, the knowledge sank into consciousness that this was a piece of paradise [Bisping 2003, my translation].

Beyond such subjective experiences lies the search of entire societies for more exotic, enchanting stimulations that test the limits of modern technical, ${ }^{19}$ financial, and intellectual achievements while at the same time questioning them. The symbolic appropriation of nature is bound to economic and political processes of appropriation. Western ideas of nature conservation are used to legitimize the expulsion of local populations from their native lands. Various apparatuses that re-assess the value of people and landscapes for global tourist markets justify these processes. During colonial times, in the era of the German Emperor William II, Kilimanjaro was visited by just a few men who symbolically possessed it by renaming it. Today, the mountain "belongs" to all those who can afford it. The wish to explore faraway lands produces marketable images and stories about the mountain. When one critically considers Kilimanjaro climbing tours, involving up to fifteen African porters and cooks, folding stools and other equipment, one cannot deny the similarity to colonial expeditions. The Tanzanian guides, and particularly the porters, mostly live in poverty while the Tanzanian and foreign (mostly male) tour operators profit. Although some guides manage to make useful international contacts in the course of their work and are invited to non-African countries, this is not the norm. ${ }^{20}$ While tourist authorities are displacing the Chagga and Maasai from their territories on the slopes of Kilimanjaro and locals are employed as porters, guides and hotel pageboys on minimal wages, most visitors live in expensive hotel complexes. All of this recalls the status quo of colonial times, which today is highly marketed as a neo-colonial "light" version. The international tourism

19 Technology, especially the ability of cameras and batteries to function at high altitudes, plays a major role for climbers of Kilimanjaro (conversations with German and French Kilimanjaro tourists at Moshi on August $11^{\text {th }} 2001$ ).

20 I received an e-mail in the year 2009 from a Tanzanian guide and interview partner who told me that one Kilimanjaro tourist had invited him and that he had travelled to Canada for three months. 
industry is grounded on a scalar hierarchy of attractions, and as Kilimanjaro ranks high on these scales the mountain is firmly in the industry's grip. While the industry is justifiably concerned with the mountain's melting snowcap, a heavenly landscape that could be destroyed by global warming within five to ten years, it is so only to the extent that the cap suits its own interests. The snowcap is measured within the projects of scale-making established first by colonialism and its scientific expeditions and presently continued by the tourism industry. Access to the mountain's top that was, according to some Chagga, formerly restricted on account of religion is today restricted by monetary means. This includes members of the local population, many of whom have found employment in the tourism industry but can access the mountain only as porters, carrying the belongings of tourists to the summit. While the mountain was once considered the property of populations inhabiting its slopes and surrounding regions, it is today the property of the postcolonial Tanzanian state and international tour operators whose joint aim is to gather revenue by collecting entrance fees and by selling hiking tours. Neither of these actors is fully aware of the mountain's pre-colonial meanings.

Further questions pertaining to social-anthropological and political ecology (Latour 2001; Robbins 2004; Gezon 2006) should be addressed to the Kilimanjaro region. In creating national parks that rob many local people of their rights, a dominant Western modernity continues to conquer yet another foreign "wilderness". On the one hand, Western modernity wishes to preserve the mountain as a freeze-frame image of the "Garden of Eden". On the other hand, the industry itself partakes of this garden's destruction: long-distance flights from Europe to Africa and energy-hungry hotel facilities at the slopes of Kilimanjaro contribute to the environmental problems, most notably global warming, threatening the park's health. Many publications on tourism and climate change focus mainly on possible financial losses for the tourism industry (e. g. Scott 2003; Elsasser and Bürki 2002) instead of challenging the underlying processes of scale-making that drive international tourism and these processes' historical roots in European colonialism. To do so might not break this vicious circle, in which nature is simultaneously celebrated and destroyed, but might at least help to further understand the political and economic strategies at play. Considerations of the appropriation of the past might give an insight into a problem that is global in scale and present in many tourist hot spots located in landscapes with a special aesthetic appeal. 


\section{REFERENCES}

ADORNO, Theodor W., 1973, Ästhetische Theorie. Frankfurt a. Main, Suhrkamp Verlag, ed. by Gretel Adorno and Rolf Tiedemann.

APG and TANAPA, 2000, Kilimanjaro: Africa's Beacon. Harare, African Publishing Group (International) and Tanzania National Parks (Tanapa), $2^{\text {nd }}$ edition.

APPADURAI, Arjun, 1996, Modernity at Large: Cultural Dimensions of Globalization. Minneapolis, University of Minnesota Press.

BAUMGARTEN, 1750-58, Aesthetika. Hamburg.

BENDER, Barbara (ed.), 1993, Landscape: Politics and Perspectives, Explorations in Anthropology.

Providence and Oxford, Berg Publishers.

BHABHA, Homi, 1994, The Location of Culture. London, Routledge.

BIANCHI, Raoul, 2003, "Place and power in tourism development: tracing the complex articulations of community and locality", PASOS: Revista de Turismo y Patrimonio Cultural, 1 (1): 13-32.

BISPING, Stefanie, 2003, “Die Launen der Elefanten”, Der Tagesspiegel, 19/10/2003.

BÖHME, Hartmut, 1995, "Einführung in die Ästhetik”, Paragrana 4 (32): 240-254.

BOOMERS, Sabine, 2004, Reisen als Lebensform: Isabelle Eberhardt, Reinhold Messner and Bruce Chatwin. Frankfurt a. M., Campus Verlag.

BRANDSTETTER, Anna-Maria, and Dieter NEUBERT (eds.), 2002, Postkoloniale Transformation in Afrika: Zur Neubestimmung der Soziologie der Dekolonisation. Münster, Lit-Verlag.

COLSON, Elizabeth, 1997, "Places of power and shrines of the land", in Ute Luig and Achim von Oppen (eds.), "The making of African landscapes”, Paideuma, Mitteilungen zur Kulturkunde, 43: 47-59.

COMAROFF, Jean, and John COMAROFF, 1993, Modernity and Its Malcontents: Ritual and Power in Postcolonial Africa. Chicago, The University of Chicago Press.

COSGROVE, Denis, 1993, "Landscapes and myth, gods and humans", in Barbara Bender (ed.), Landscape: Politics and Perspectives, Explorations in Anthropology. Providence and Oxford, Berg Publishers, 37-61.

CRICK, M., 1989, "Representations of international tourism in the social sciences: sun, sex, sights, savings, and servility", Annual Review of Anthropology, 18: 307-344.

DESCARTES, René, 1984 [1649], Die Leidenschaften der Seele. Hamburg, Meiner, edited and translated by Klaus Hammacher.

DESCOLA, Philippe, and Gisli PÁLSSON (eds.), 1996, Nature and Society. London, Routledge.

DILGER, Hansjörg, and Urte Undine FRÖMMING, 2004, "Einleitung: moderne und postkoloniale Transformation in einer vernetzten Welt", in Dilger et al. (eds.), Moderne und postkoloniale Transformation: Schrift zum 60. Geburtstag von Ute Luig. Berlin, Weißensee Verlag, $1-17$.

DUNDAS, Charles, 1968 [1924], Kilimanjaro and its People. London, Cass.

EARLE, Timothy, 2001, "Institutionalization of chiefdoms: why landscapes are built", in J. Haas (ed.), Leaders to Rulers. New York, Kluwer Academic/Plenum Publishers, 105-124. ELSASSER, Hans, and Rolf BÜRKI, 2002, "Climate change as a threat to tourism in the Alps", Climate Research, 20: 253-257.

ESCOBAR, A., 1991, "Anthropology and the development encounter: the making and marketing of development anthropology", American Ethnologist, 18 (4): 658-682. 
FRÖMMING, Urte Undine, 2001, "Volcanoes: symbolic places of resistance: political appropriation of nature in Flores, Indonesia”, in Ingrid Wessel and Georgia Wimhöfer (eds.), Violence in Indonesia. Hamburg, Abera Verlag, 270-281.

— , 2002, "Vulkane und Gesellschaft: Naturaneignung auf Flores, Indonesien", in Ute Luig and Hans-Dietrich Schultz (eds.), "Natur in der Moderne: Interdisziplinäre Ansichten", Berliner Geographische Arbeiten, 93: 165-186.

— , 2004, "Schneeschmelze am Kilimanjaro: über die touristische Aneignung afrikanischer Natur in der ästhetischen Moderne", in Dilger et al. (eds.), Moderne und postkoloniale Transformation: Schrift zum 60. Geburtstag von Ute Luig. Berlin, Weißensee Verlag, 258-274.

—, 2006, Naturkatastrophen: Kulturelle Deutung und Verarbeitung. Frankfurt a. M., Campus Verlag.

— , 2008, "Klimawandel und Naturgefahren: historische Prädispositionen", in Bernd Herrmann (ed.), Beiträge zum Göttinger Umwelthistorischen Colloquium. Göttingen, Universitäts Verlag Göttingen, 65-85.

GEILINGER, Walter, 1930, Der Kilimanjaro: Sein Land und Seine Menschen. Bern, Huber.

GEZON, Lisa L., 2006, Global Visions, Local Landscapes: A Political Ecology of Conservation, Conflict, and Control in Northern Madagascar. Plymouth, AltaMira Press.

GROH, Ruth, and Dieter GROH, 1996, Die Außenwelt der Innenwelt: Zur Kulturgeschichte der Natur, 2. Frankfurt a. M., Suhrkamp Verlag.

GUTMANN, Bruno, 1932-38, Die Stammeslehren der Dschagga, vols.1-3. Munich.

HABERMAS, Jürgen, 1985, Der Philosophische Diskurs der Moderne. Frankfurt a. M., Suhrkamp Verlag.

HAMILTON, Lawrence S., and Graeme W. WORBOYS, 2003, "Mountain protected areas", update No. 38, June 1, World Commission on Protected Areas/IUCN 2003. Available at <http://www.mtnforum.org/resources/library/hamil03b.htm > (accessed 3/1 1/2003).

HEGEL, G. W. F., 1927-30, Vorlesungen über die Geschichte der Philosophie. Stuttgart, edited by H. Glockner.

HONOLD, Alexander, 2000, "Zum Kilimandjaro! Über die Faszination exotischer Berge und die Stationen ihrer Entzauberung”, Tourismus Journal: Zeitschrift für tourismuswissenschaftliche Forschung und Praxis, 4 (4): 519-537.

JOHNSTON, Harry Hamilton, 1886, The Kilimanjaro Expedition: A Record of Scientific Exploration in Eastern Equatorial Africa and a General Description of the Natural History, Languages and Commerce of the Kilima-Njaro District: London. Kegan Paul, Trench, and Co.

LARKIN, Brian, 1997, "Indian lovers and Nigerian lovers: media and the creation of parallel modernities”, Africa, 67 (3): 406-440.

LATOur, Bruno, 2001, Das Parlament der Dinge: Für eine Politische Ökologie, Frankfurt a. M., Suhrkamp Verlag.

LI, T.M., 1999, "Compromising power: development, culture, and rule in Indonesia", Cultural Anthropology, 14 (3): 295-322.

LUIG, Ute, 2002, “Die Victoriafälle: touristische Eroberung, Vermarktung und Inszenierung von natur", in Ute Luig and Hans-Dietrich Schultz (eds.), "Natur in der Moderne: Interdisziplinäre Ansichten”, Berliner Geographische Arbeiten, 93: 255-274.

LUIG, Ute, and Achim VON OPPEN, 1997, "Landscape in Africa: process and vision, an introductory essay", Paideuma: Mitteilungen zur Kulturgeschichte, 43: 7-45.

MEGHJI, Zakia, 2001, "Meghji promises big change in tourist services", Sunday Interview with Zakia Meghji. Sunday News, Tanzania, 29/07/2001. 
MEYER, Hans, 1888, Zum Schneedom des Kilimandscharo: 40 Photographien aus Deutsch-Ostafrika mit Text. Berlin, J. Meidinger.

—, 1890, Ostafrikanische Gletscherfahrten: Forschungsreise im Kilimandscharo-Gebiet. Leipzig, Duncker \& Humblot.

—, 1900, Der Kilimandjaro: Reisen und Studien. Berlin, Reimer.

—, 1928, Hochtouren im Tropischen Afrika. Leipzig, Brockhaus.

MOORE, Sally Falk, 1986, Social Facts and Fabrications: Customary Law on Kilamanjaro 18801980. Cambridge, Cambridge University Press.

MOORE, Sally Falk, and Paul PURRIT, 1977, The Chagga and Meru of Tanzania, published with an introduction by William M. O'Barr. International African Institute, series Ethnographic Survey of Africa, East Central Africa.

MORISON, Theodore, 1933, "The Wachaga of Kilimanjaro: Reminiscences of a war-time district officer”, African Affairs, XXXII: 140-147.

NEUMANN, Roderick P., 1998, Imposing Wilderness: Struggles over Livelihoods and Nature Preservation in Africa. Berkeley, Berkeley University Press.

NEVELING, Patrick, and Carsten WERGIN, 2009, "Projects of scale-making: new perspectives for the anthropology of tourism", this volume.

NICOLSON, Marjorie Hope, 1959, Mountain Gloom and Mountain Glory: The Development of the Aesthetics of the Infinite. New York, W. W. Norton \& Company.

RANDEIRIA, Shalini, 1999, "Geteilte Geschichte, verwobene Moderne", in Jörn Rüsen, Hanna Leitgeb and Norbert Jegelka (eds.), Zukunftsentwürfe: Ideen für eine Kultur der Veränderung. Frankfurt a.M., Campus Verlag, 87-96.

REBMANN, J., 1858, "Bericht einer Reise zum Kilimandscharo”, in J. L. Krapf, Reisen in OstAfrika ausgeführt in den Jahren 1837-55. Stuttgard, Kornthal.

ROBBInS, Paul, 2004, Political Ecology: A Critical Introduction. Malden, MA, and Oxford, UK, Basil Blackwell Publishing.

ROUSSEAU, Jean-Jacques, 1964 [1761], "Julie ou La Nouvelle Heloïse”, in Jean-Jacques Rousseau, CEuvres complètes II. Paris, Gallimard, 1-745.

SCHAMA, Simon, 1995, Landscape and Memory. London, Vintage Books.

SCHANZ, Johannes, 1913, Mitteilungen über die Besiedlung des Kilimandscharo durch die Dschagga und deren Geschichte. Leipzig, Baessler-Archiv, Beiheft 4.

SCOTT, Daniel, 2003, "Climate change and tourism in the mountain regions of North America", presented at the $1^{\text {st }}$ International Conference on Climate Change and Tourism, Djerba, Tunisia, 9-1 1 April.

SEEL, Martin, 1996, Eine Ästhetik der Natur. Frankfurt a.M., Suhrkamp Verlag.

SEMALI, Ladislaus M., and Joe KINCHELOE, 1999, "What is indigenous knowledge and why should we study it?", in Ladislaus M. Semali and Joe Kincheloe (eds.), What is Indigenous Knowledge? Voices from the Academy. New York, Taylor and Francis.

SHIVII, I. G. (ed.), 1973, Tourism and Socialist Development. Dar-es-Salaam, Tanzania Publishing House.

THOMPSON, David, 1971, Petrarch: A Humanist among Princes: An Anthology of Petrarch's Letters and of the Selections from His other Works. New York, Harper and Row.

THOMSON, Joseph, 1885, Through Masai Land: A Journey of Exploration among the Snowclad Volcanic Mountains and Strange Tribes of Eastern Equatorial Africa Being the Narrative of the Royal Geographical Society's Expedition to Mount Kenia and Lake Victoria Nyanza, 18831884. Boston and New York, Houghton, Mifflin, and Company. 
TSING, Anna, 2000, “A global situation”, Cultural Anthropology, 15 (3): 327-360.

VIETTA, Silvio, and Dirk KEMPER, 1998, Ästhetische Moderne in Europa: Grundzüge und Problemzusammenhänge seit der Romantik. Munich, Wilhelm Fink.

VOLKENS, Georg, 1897, Der Kilimandscharo: Darstellung der allgemeineren Ergebnisse eines fünfzehnmonatigen Aufenthalts im Dschaggalande. Berlin, Reimer.

WEBER, Max, 1920, Gesammelte Aufsätze zur Religionssoziologie, vol. I. Tübingen, Mohr Siebeck.

WEISS, Kurt 1886, Meine Reise nach dem Kilimandscharogebiet im Auftrage der Deutsch-Ostafrikanischen Gesellschaft. Berlin.

WHITEHEAD, Alfred North, 1987 [1929], Prozeß und Realität: Entwurf einer Kosmologie. Übersetzt und mit einem Nachwort versehen von Hans Günter Holl. Frankfurt a. M., Suhrkamp Verlag.

WINTER, Christoph J., 1994, "Some problems of Chagga identity", in Thomas Geider and Raimund Kastenholz (eds.), Sprachen und Sprachzeugnisse in Afrika: Eine Sammlung Philologischer Beiträge Wilhelm J. G. Möhlig zum 60. Geburtstag zugeeignet. Cologne, RüdigerKöppe, 459-471.

WOZNIAKOWSKI, Jacek, 1987, Die Wildnis: Zur Deutungsgeschichte des Berges in der Europäischen Neuzeit. Frankfurt a. M., Suhrkamp Verlag.

O degelo dos glaciares do Kilimanjaro: percepção e apropriação colonial e pós-colonial da natureza africana - Urte Undine Frömming • Freie Universität Berlin, Alemanha • fromming@ zedat.fu-berlin.de

Ao longo da última década, o degelo dos glaciares do Kilimanjaro tornou-se um símbolo dos efeitos do aquecimento global. Simultaneamente, o aumento do turismo na região tem um carácter ambivalente, já que a indústria ganha com a celebração da natureza (e sua apropriação pelo Ocidente), a mesma natureza que é ameaçada pela enorme influência do turismo sobre o clima mundial. Nas percepções europeias, o monte Kilimanjaro tornou-se, desde a sua descoberta no século XVIII, epítome da beleza avassaladora, sendo até hoje representativo do estado selvagem e da aventura para os mais de 20 mil turistas estrangeiros que sobem a montanha todos os anos. Este artigo identifica os modos como tais percepções se inscrevem nos fundamentos da modernidade estética que continuam a moldar a atracção pelo monte Kilimanjaro. A análise prossegue centrando-se nas suas consequências para a população local e nas relações entre os habitantes locais e os visitantes estrangeiros que são atraídos pelos projectos de configuração de escala de uma indústria que dá continuidade à conquista colonial.

KEYWORDS: Kilimanjaro, escala, turismo, natureza, estética. 